\title{
The World as a Theological Problem
}

\author{
Martin Koci \\ Institut für Philosophie, Universität Wien, Österreich \\ martin.koci@univie.ac.at
}

\begin{abstract}
We have no other experience of God but the human experience, claims Emmanuel Falque. We - human beings - are in the world. Whatever we do, whatever we think and whatever we experience happens in the world and is mediated by the manner of the world. This also includes religious experience. Reflection on the possibility of religious experience - the experience of God - suggests that the world is interrupted by someone or something that is not of the world. The Christian worldview makes the tension explicit, which is perhaps why theology neglects the concept and fails in any proper sense to address the world. Through following the phenomenologist Jan Patočka, critiquing the theologian Johann B. Metz and exploring the theological turn in phenomenology, I will face the challenge and argue for a genuine engagement with the world as a theological problem.
\end{abstract}

\section{Keywords}

world - theology - phenomenology - Jan Patočka - Michel Henry - Emmanuel Falque

We have no other experience of God but the human experience

EMMANUEL FALQUE 


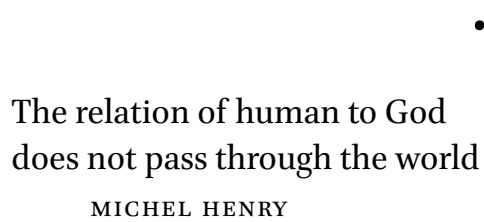

$\bullet \bullet \bullet$

The relation of human to God

MICHEL HENRY

Eugen Fink once suggested that despite its breath-taking development in modernity, science never reached the world. ${ }^{1}$ The orientation on beings (Seiendes) prevents the scientific explorer from seeing the whole: the focus on the objective makes the insight impossible and the horizon of the world is lost. The same charge, I would suggest, can be brought against theology. Theology typically explores divine revelation as something objective, that is, as something positively given and received. Theology is therefore tempted to overlook the phenomenality of that which is deemed to be divine revelation. In other words, theology neglects the horizon where God's manifestation to human beings and human openness to transcendence take place. Worse still, theology sees the world as an external rather than internal problem and so fails to see it as a challenge to its own thinking. This claim is central to this paper. My goal is not, however, merely to identify a lacuna in theological reasoning. Rather, I will offer a critical and constructive account of thinking the possibility of the appearance of transcendence which is not of the world (Jn 8:23), but which still appears and is experienced in the world (Jn 3:16-17). In short, I will explore the world as a theological problem.

Phenomenology boasts a long tradition of investigating the concept of the world. Husserl's pioneering work, developed in diverging directions by Fink and Heidegger, offers abundant inspiration for the philosophy of religion. I have nonetheless chosen a different guide to the problematic under consideration - the Czech phenomenologist Jan Patočka. First, Patočka will provide us with the analytics of the concept of the world not only as a philosophical problem, but also with explicit attention to openness to God from within the world and will thus highlight for us the theological relevance of the inquiry. Secondly, I will explore the theological debate and show that the world is a question that is often overlooked or even completely forgotten in contempor-

1 Eugen Fink, Einleitung in die Philosophie (Würzburg: Königshausen \& Neumann, 1985), p. 96. 
ary theology. Authors such as Johann B. Metz have attempted to formulate a theology of the world, but I will argue that these undertakings do not conceive the world as a genuine theological problem. Thirdly, and finally, I will turn to the field which I believe is the appropriate place to consider the world as a theological problem, and that is in the New Phenomenology, ${ }^{2}$ otherwise known as the theological turn in continental philosophy. ${ }^{3}$ In addition to establishing the world as a theological problem in its profundity, I will further argue for a novel reading of the widely discussed movement of theologically attuned phenomenology from a fundamental theological perspective and will suggest that phenomenology provides theology with a new and much-needed philosophical foundation.

Jan Patočka's Habilitationsschrift of 1936 The World as a Philosophical Problem launches his life-long project of a search for the natural world. Following in the footsteps of Husserl, who discovered the loss of Lebenswelt in his Crisis of the European Sciences, Patočka scrupulously follows the problem right up to his mature works of the 196os and 1970s. ${ }^{4}$ Paul Ricoeur rightly claims that Patočka's most original contribution to post-Husserlian phenomenology is his unfolding of the idea of the natural world as the central phenomenological problem. ${ }^{5}$ Numerous studies have investigated Patočka's project in some detail, focusing in particular on Patočka's original solution concerning the question of meaning given and revealed 'for us' in the world but avoiding the temptation of both metaphysical objectivism and relativistic subjectivism. ${ }^{6}$ The aim of this paper

2 See, for example, Aaron J. Simmons and Bruce E. Benson, The New Phenomenology: A Philosophical Introduction (New York: Bloomsbury, 2013).

3 Dominique Janicaud, 'The Theological Turn of French Phenomenology', in D. Janicaud et al., Phenomenology and the 'Theological Turn': The French Debate (New York: Fordham University Press, 2000), pp. 16-103. See also the recently published special issue, 'The Future of the Theological Turn', Philosophy Today 62:1 (2018), 89-197.

4 Key works include: Jan Patočka, The Natural World as a Philosophical Problem, with supplement 'The Natural World Remeditated Thirty-Three Years Later' (Evanston: Northwestern University Press, 2016); 'The Natural World and Phenomenology', in E. Kohák, ed, Jan Patočka: Philosophy and Selected Writings (Chicago: University of Chicago Press, 1989), pp. 239-272; An Introduction to Husserl's Phenomenology (Chicago and La Salle: Open Court, 1996); Body, Community, Language, World (Chicago and La Salle: Open Court, 1998).

5 Paul Ricoeur, 'Jan Patočka: de la philosophie du monde naturel à la philosophie de l' histoire', Studia Phenomenologica 7:1 (2007): 193-200.

6 Erazim Kohák, 'The Crisis of Rationality and the Natural World', The Review of Metaphysics 
is not to add to the internal phenomenological debate but to draw implications from Patočka's thought for the timely discussion within the field of the theological turn, for which, perhaps unexpectedly, Patočka proves to be a valuable option.

In January 1975, Patočka delivered a fascinating lecture at the invitation of divinity students entitled 'Christian Faith and Thinking'; the transcribed text was later published as 'Christianity and the Natural World.' ${ }^{7}$ This title corresponds more closely to the content of the lecture, which explored the matter of dealing with the divine and God from the perspective of the natural world. What we have here, therefore, is Patočka's unique attempt to connect phenomenological philosophy with the field of theology.

Patočka opens his exposition with an explanation of how the natural world is conceived in phenomenology, and why it is important to reflect on the question: "The natural world is simply the world we live in. It is the world we meet and whose things, contents and affairs we encounter as soon as we open our eyes and meet things and our neighbours. It is the world of which we have understanding as humans.'8 Thinking the natural world - the life-world - is thinking a critical distance from the world as presented according to the modern techno-scientific mentality. The natural world is not nature in the sense of the objective knowledge of the natural sciences. It is not the world, as Patočka stresses, that is created in the laboratory. The natural world refers to our reality as it gives itself to us: the 'life-world' is the world we live in.

We must be more precise, however. First, whether or not we are aware of the natural world, whether or not we have a concept in mind, we are in the world. Before one begins to think, to reflect and to formulate theories - scientific or philosophical - concerning the meaning of the world, one has the world. Secondly, when phenomenologists, Patočka included, talk about the world, it is always the world of human beings. Or, to put it the other way, whenever one asks questions about the human situation, one refers to the natural world the world of life. In short, the world is history, context and a movement. And here, in our perception of a world that is intrinsically linked with being human,

40:1 (1986), 79-106; Renaud Barbaras, L'ouverture du monde: Lecture de Jan Patočka (Chatou: Édition de la transparence, 2011); Karel Novotný, 'Pohyb života a svět: $\mathrm{O}$ fenomenologii a metafyzice světa u Jana Patočky', Reflexe 53 (2017), 139-155. Miroslav Petř́ček, 'Jan Patočka a myšlenka přirozeného světa', Filosofický časopis 38:1-2 (1990), 22-43.

7 The original Czech version 'Křest'anství a přirozený svět' was published only in a samizdat edition. A French translation is available: 'Le christianisme et le monde naturel', Istina 38:1 (1993), 16-22. In this paper, I use the original Czech version deposited in the Patočka Archive at the Institut für Wissenschaften vom Menschen in Vienna (all translations are mine).

8 Patočka, 'Křest'anství', 3 . 
is where we clash with the modern techno-scientific mentality as conceived by Husserl in Crisis, criticized by Heidegger in The Question Concerning Technology, and reflected on by Patočka in The Natural World as a Philosophical Problem.

According to Patočka, 'we modern people' have no direct access to the natural world of our experience. Instead, we live in a world of 'objective and objectivized experience. ${ }^{9}$ Modernity has lost all sense of the natural world and replaced Lebenswelt with 'a modern mathematical-physical and generally objective and objectivized world'.10

One of the consequences of the loss of the natural world, Patočka explains, is the loss of a religious perception of the world. For the ancient Greeks, the world contained the divine principle and the deities revealed themselves to human beings. In other words, the divine was a natural part of the world. The Judeo-Christian tradition rejects this Greek idea. God is not the principle of the world but its creator. And although - as we will see in the next section - this will later be used as a theological argument for the autonomy of the world, the pre-modern Jews and Christians, like their ancient counterparts, undoubtedly experienced Lebenswelt Gottes. ${ }^{11}$ In this context, Patočka raises a crucial question: 'Is there anything in the natural world like an originary approach to the divine? Is there anything like an original human understanding of the sacred and the divine?'12 Here Patočka parts company from Husserl, who rejects the theme of the divine in relation to the natural world. For Patočka, the relevance of these questions can be seen in the fact that human beings, despite all modern techno-scientific obfuscations, nevertheless live in the natural world. Patočka's questions can therefore be read as a meditation on whether in fact the loss of a religious perception of the world might not result in a deficient form of the natural world. Is there something missing in a world in which there is no place for God?

No less surprising than the question is the proposition Patočka makes: to reconsider the problem of the natural world in its authenticity means to deconstruct - here Patočka uses the Heideggerian term Destruktion - modern objectivization and thus tear down the principal source of concealment of the world, which leads, in Patočka's view, to the recognition that before, 'there has always been something like an understanding of the divine and the sacred in the nat-

\footnotetext{
$9 \quad$ Ibid., p. 4.

10 Ibid., p. 4.

11 Ibid., pp. 4-5.

12 Ibid., p. 5 .
} 
ural world of human beings. ${ }^{\prime 3}$ In sum, the Lebenswelt has always had an aspect of the Lebenswelt Gottes. This may seem a surprising answer from a philosopher who insists that there is no way for the philosopher other than to 'eternally walk the earth'.

If we follow Patočka's line of thought regarding the natural world and the problem of modernity, we will discover that the religious moment plays an important role in his argument. Early works such as the 1936 essays 'Masaryk and Husserl on the conception of crisis' show that for Patočka, the loss of the natural world is caused not only by mathematical-scientific mastery over the world (the Husserlian line) but also by the loss of a religious perception of the world (as drawn from Masaryk). ${ }^{14}$ The multi-layered work 'Supercivilization and its inner conflict', most likely written in the 1950s, contains a striking passage in which Patočka argues that one of the causes of the decline of modernity is the loss of what he calls vertical thinking.$^{15} \mathrm{~A}$ reference to the capacity for reason in Christianity is clear in this respect. ${ }^{16}$ The essay 'Christianity and the Natural World' provides the backbone of our argument and asserts the desolation caused by the absence of the divine in the world. Hence, to borrow from Ricoeur, Patočka not only claimed allegiance to Husserl's project and turned it into a life-long search for the natural world, but also, I suggest, restated the question by bringing the religious (even theological) element into play, thus making the case for the theological turn long before the movement took shape in the wake of the publication of Janicaud's critical pamphlet in 1991.

Patočka and other phenomenological philosophers remind us that even those philosophers who have their feet placed firmly on the earth and who consciously move on the plane of immanence cannot always resist looking skywards or perhaps even longing to touch the stars. ${ }^{17}$ Earth and sky are key coordinates in Patočka's treatment of the natural world: ${ }^{18}$ one provides the

13 Ibid., p. 6.

14 Jan Patočka, 'Spiritual Crisis of European Humanity in Husserl and Masaryk', in J. Novák, ed, On Masaryk (Amsterdam: Rodopi, 1988), pp. 97-109.

15 Jan Patočka, 'La surcivilisation et son conflit interne', in Liberté et sacrifice (Grenoble:J. Millon, 1990), pp. 99-177.

16 I have offered an interpretation of this particular place in Patočka elsewhere: Martin Koci, Thinking Faith after Christianity: A Theological Reading of Jan Patočka's Phenomenological Philosophy (Albany: SUNY Press, 2020), pp. 75-82.

17 'The philosopher knows that he must eternally walk the earth. But what is the earth? It may be that its peaks touch the stars. It may be that its abysses contain the deepest mystery.' Jan Patočka, 'Theologie a filosofie', in I. Chvatík and P. Kouba, eds, Sebranné spisyJana Patočky, vol. ı. Péče o duši, I (Praha: Oikoymenh, 1996), pp. 15-21 at p. 19.

Patočka, 'Natural World Remeditated', p. 175. 
anchor for life and everything that is, the other the necessary distance from illusory ready-made meaning. The tension between the two is what reveals the problematicity of the world, sets Patočka free from Husserl, and leads him in the direction of an existentially engaged phenomenology. ${ }^{19}$

Central to such a phenomenology is the problem of religion, or more particularly the question of Lebenswelt Gottes. Patočka differentiates between Ancient Greece and Rome on the one hand, and the relationship to the divine as it appears to the Christian on the other. ${ }^{20}$ For the Greeks and Romans, the divine was the principle present in the world: nothing happens outside the agency of the divine. Such a world interwoven with divine actions can also be found in Old Testament Judaism: God, the Lord himself, fights His own battles and is present in every action of His people. 'The Lord gave and the Lord hath taken away' (Job 1:21). Leon Feuchtwanger's Jephthah's Daughter presents an excellent literary portrait of a natural world pierced by the divine: the final dramatic scene of the sacrifice of Judge Jephthah's only child is narrated as the direct action of God. Although he ruminates on the possibility of disobeying God, Jephthah knows God's will is inescapable. The world is full of God.

Patočka suggests that such a reading of the religious conception of the natural world is something utterly foreign to, and indeed inaccessible to, 'modern people'. Christianity interrupted the ancient religious world, and it is no accident that early Christians were known pejoratively as atheists. For Patočka nevertheless, the centre of gravity is the tension between the naivety and superstition from which modernity - and even Christianity in many respects - freed the human being, and openness to the divine in the midst of a world that seems not to be in favour of such openness. In his own words: 'We are facing a peculiar situation. Where openness is a matter of fact, there are contents we cannot accept. ${ }^{21}$

Here we should recall Patočka's notion of the world as history and as a movement: the world is not simply static nature undergoing evolution but an historical movement of understanding. Like Thomas Kuhn's theory of paradigm shifts, Patočka suggests that this movement of understanding opens some doors but closes others: modern people cannot access the divine in the same way as did the Greeks or medieval people; human life and the world are two sides of the same movement.

19 Ivan Blecha, 'Pojem světa u Finka a Patočky', in V. Leško and R. Stojka, eds, Patočka a filozofia 20. storočia (Košice: Filozofická fakulta UPJš v Košiciach, 2015), pp. 151-168 at pp. 157-163.

20 Patočka, 'Křest’anství', p. 7.

21 Ibid., p. 8. 
It is in this context that Patočka raises a provocative question: 'I wonder: does such an historical change not also apply to that which concerns us most, that is, the self-understanding of human being and the self-understanding of being human in relation to what is divine and God?'22

Patočka affirms that the Christian experience of God is fundamentally different from the ancient experience of Lebenswelt Gottes: for Christianity, a relationship with God is an historical experience addressed to an individual being; in the Christian perception, understanding God and understanding the world are not static units. In its very essence, Christianity is a movement. ${ }^{23}$ The most fitting way to describe this existential Christian kinesthesis would therefore be the concept of transformation - more of which later. Towards the end of 'Christianity and the Natural World', Patočka meditates on the fact that although the experience of openness appears to bring transformation, something significant remains unchanged. What shall we make of this dynamic metaphysics of transformation?

Here we are touching on the heart of the matter. The world as a philosophical problem becomes a theological problem; or the two are at least shown to be two sides of the same coin. ${ }^{24}$ The crucial issue is understanding the divine and God-in-the-world. The problem concerns not so much knowledge of God but openness to the possibility of God's appearance in the world.

I conclude by drawing a two-fold outcome from Patočka which nonetheless goes beyond Patočka's own argument. First, the world as a theological problem concerns the possibility of the appearance in the world of that which is not of the world but always appears by way of being-in-the-world. Second, the world as a theological problem is about exploring the possibility of approaching God from the perspective of the openness in the world, that is, the perspective of a movement of understanding which originates in the world, and thus from something a priori, from something given. Patočka's question in 'Christianity and the Natural World' seeks to recover openness to the divine in the world and at the same time to affirm the evential nature of the world and life, that is, the perception of the life-world as an existential movement. Patočka's point is not

22 Ibid., p. 10.

23 An oft-quoted place from Patočka's Heretical Essays suggests a similar idea: 'Christianity remains thus far the greatest, unsurpassed but also un-thought-through human élan that enabled humans to struggle against decadence.' Jan Patočka, Heretical Essays in the Philosophy of History (Chicago and La Salle: Open Court, 1996), p. 108 [translation modified].

24 Or opposite banks of one river as Emmanuel Falque has recently suggested in Crossing the Rubicon: The Borderlands of Philosophy and Theology (New York: Fordham University Press, 2016), in which he proposed his thought-provoking maxim 'the more we theologize, the better we philosophize' (p. 147). 
to revive former religious conceptions of the world - the Lebenswelt Gottes of the Greeks, early Christians or medieval thinkers - but to enter the possibility of the appearance of the divine in the world, that is, of openness to phenomena not of this world but appearing in the world. What is implicit is the consciousness that the world is both a philosophical problem and a theological problem. The philosophical discourse of reasoning must stop here, however, and be replaced by a challenge to theology to understand itself as an evential-historical movement of thinking and to reflect on the human being-in-the-world interrupted by a call which happens in the world but is not of the world.

\section{Towards a Theology of the World}

Theology begins to adopt 'the world' as a theme in the second half of the twentieth century. There are three reasons for this: (1) The debate in post-Husserlian phenomenology was a little 'up in the air'. Theology did not engage with Husserl or phenomenology explicitly, but Heidegger's analytics of Dasein did not go unnoticed in theological circles. The debate led to drawing inspiration from (existential theology) as well as clear opposition to (dialectical theology) the state of being thrown into the world. (2) Modern theologians, whether they liked it or not, faced the same human conditions as the rest of the intellectual community, and it doesn't take a phenomenological genius to see that modern science completely reshaped the conception of the world and that because mathematization, objectivization and thinking more geometrico turned the natural world into a philosophical problem, theology was forced to engage with a complete loss of the natural religious perception of the world and therefore came under immense pressure. (3) The problem of secularization and its coming to the fore in historical-sociological scholarship greatly affected the theological debate and called for a fresh justification of Christianity in the midst of a profane world. From a theological perspective, the problem becomes a question concerning the autonomy of the world (and of the subject, and of culture), ${ }^{25}$ that is, concerning the tension between the modern and Christian worldviews.

One theologian closely engaged in discussions concerning the problem of the world is Johann B. Metz, especially in his Zur Theologie der Welt, which

25 These tensions were prophetically discussed in the work of Romano Guardini. See, for example, Das Ende der Neuzeit: Ein Versuch zur Orientierung (Würzburg: Werkbund Verlag, 1959); Welt und Person: Versuche zur christlichen Lehre vom Menschen (Würzburg: Werkbund Verlag, 1955). 
serves as an exemplar for the theological debate. The crux is the question of 'the Christian understanding of the world' in two senses: Christian self-definition in a secular and secularizing world; and the Christian conception of the world beyond its being God's creation, a sense which is lost in modernity.

Metz first attempts to elucidate the concept of the 'worldliness of the world' (Weltlichkeit der Welt) which comes to the fore in modernity. Metz talks about modernity in the German sense of Neuzeit, which relates to a broader historical period than the modernity of scientific revolutions. Neuzeit implies emancipation from the religious interpretative framework of everything that is. On this basis, Metz understands the world as an autonomous horizon of being. Interestingly, he suggests that Weltlichkeit der Welt is a Christian concept.

How can we reconcile the tension between the pre-modern Christian Weltanschauung and the supposed Christian authenticity of the modern point of view? Metz builds his argument on the doctrine of the Incarnation. The fact (of faith) that God has taken flesh and entered the world and in this kenotic movement has accepted the world leads Metz to affirm that the autonomy of the world as proclaimed in modernity is in fact implicitly presupposed in Christianity.

Die Weltlichkeit der Welt, wie sie im neuzeitlichen Verweltlichungsprozeß entstand und in global verschäfter Form uns heute anblickt, ist in ihrem Grunde, freilich nicht in ihren einzelnen geschichtlichen Ausprägungen, nicht gegen, sondern durch das Christentum entstanden; sie ist ursprünglich ein christliches Ereignis damit die innergeschichtliche waltende Macht der Stunde Christi in unserer Weltsituation. ${ }^{26}$

Metz nonetheless adds that the tension established by the cross of Christ is not diminished: the world in the Christian perspective is always ambivalent. Although it is unconditionally accepted by God through the Incarnation, the world resists this acceptance. There are therefore different degrees of the autonomy of the world. The modern turn to the world functions as the anamnesis of an authentic Christian understanding of the world. Here Metz repeats Guardini's point (in Die Welt und die Person) that the emancipation of modernity in its understanding of the world as autonomous in fact helps Christianity see its own truth even more clearly. ${ }^{27}$ After clarifying the genealogical principle of the relationship between the concept and Christianity, Metz moves

26 Johann B. Metz, Zur Theologie der Welt (Main-München: Matthias-Grünewald, Kaiser Verlag, 1969), pp. 16-17.

27 See, for example, Guardini, Welt und Person, pp. 24-26. 
on to the theological signification of the world, raising the question: What is the world in the Christian perspective (Weltverständnis in Glaube)?

First, from Metz's theological perspective, the world is an anthropological concept not a cosmological-objectivist one. ${ }^{28}$ The world is not simply the sum of beings, that is, things (Seiendes), but the world of humans (die Welt des Menschen). Secondly, as illustrated by the fall (sin) and the promise of salvation understood as a new creation - a new world which is now-but-not-yet the world is a place of happening. Which leads Metz to a third point, namely the evential-historical character of the world. In his own words: 'Die Geschichte kommt nicht zu einer an sich konstituierten Welt-Natur nachträglich hinzu, sie gehört vielmehr in die ontologische Konstitution der Welt selbst.'29

This three-fold definition seems to place Metz strikingly close to the phenomenological analysis of the world presented in post-Husserlian thought. Phenomenology and theology part company on the question of God and his relation to the world.

Merleau-Ponty insists that the Incarnation changes everything: it is the logic of the Incarnation which establishes a link between God and the world. God is not the principle of the world, as the Greeks would have it. God does not dwell in the world as a pagan deity. God interrupts the world and enters the world - by revelation, and most radically by adopting flesh and finitude. Faith demythologizes the world and deprives it of its magic and enchantment. The world remains profane; the world as a free and creative act of God guarantees its worldliness. ${ }^{30}$

For Metz, the consequences are clear. The secular (atheist) struggle against Christianity is a misunderstanding. The process of worlding the world as manifested in Christianity via (1) the world of humans (the anthropological conception), (2) the world as a movement, and (3) the world as an evential-historical being is an outcome of the theological event of Christ. In short, the Christian conception of the world is mirrored in the secular. Metz goes even further. It is Christian doctrine which makes it possible to, for example, (1) emancipate politics from the sacred realm, (2) develop modern science as autonomous, independent and free from religious prejudice, and (3) distinguish nature (creation) from God. Christianizing the world is not about going back to premodern conceptions but about making the world more human and historical.

To offer a preliminary conclusion, Metz's theology of the world represents a positive approach to the process of secularization and an attempt to incorpor-

\footnotetext{
28 Metz, Zur Theologie, p. 20.

29 Ibid., p. 21.

3o Ibid., p. 23.
} 
ate it into the theological narrative (I will come back to this point). The modern anthropological turn is taken as the anamnesis of - or even as a sharper manifestation of - the Christian truth that the world is Geschichtswelt and Die Welt des Menschen. In negative terms, the world is not kosmos understood as nature. The experience of being-in-the-world (Welterfahrung) is not a relationship of subject-object but of Ich und $D u$, as Martin Buber would put it. The world is the horizon of subject-subject relations, that is, the relationship of an 'I' with others in the world and with the Other of the world.

In contrast to the experiential basis of phenomenology, a theology of the world as we find in Metz and other theologians of his day ${ }^{31}$ offers a faithbased understanding of the concept of the world (Weltverständnis in Glaube). Although theology affirms a dynamic conception of the world (the eventialhistorical), it has become clear that conclusions concerning the world are drawn first and foremost from posited revelation and are only subsequently applied to the problem. For example, the worldliness of the world (Weltlichkeit der Welt) is recuperated as a Christian category and the process of secularization is rendered as the evolution of Christianity. ${ }^{32}$

It may be that from the position of a deliberate decision of faith, this is all legitimate. I find this vision too hasty, however, too schematic, and even shallow and superficial. Theologies of the world become paradoxical. On the one hand, theology affirms the loss of a religious conception of the world as an authentic theological development: the world is not sacred; its profane nature corresponds to the logic of the Creation and the Incarnation. On the other hand, theology postulates a definition of the world from revelation that is given and accepted. The main problem here is not that Heidegger's critique of theology as positive science - the science of faith - is apposite. My point is that theology misses the real problem.

Theologies of the world tell the story of how the religious understanding of the world was disrupted in modernity and replaced by claims of human autonomy, human reason and the autonomy of the world. Theology embraces the modern critique and recuperates it as its own. Henceforth, the world is interpreted as the correlate of the human being of faith. The result is an existential, correlational and historical theology which 'saves' the world from the

31 See, for example, Edward Schillebeeckx, World and Church (London-New York:T\&T Clark, 2014).

32 In this respect, Gianni Vattimo's hermeneutical take on secularization as the unfolding of Christianity is a repetition of the same movement exercised by Metz and Tillich (on the Protestant side) in the 196os. See Gianni Vattimo, After Christianity (New York: Columbia University Press, 2002). 
perspective of faith and renders secularization a legitimate evolution of Christianity and even a call - vocation - to practical life in the world. The attempt to formulate a theology of the world, therefore, 'merely' explains the world on the basis of revelation received and accepted as something not of the world. The question of Lebenswelt (even as Lebenswelt Gottes) is not raised, however. There are two possible explanations for this: either Christian theology upholds the experience of the natural world, the world of lived experience, in the turmoil of the present crisis as we find it in phenomenological discussion; or, more probably, theology simply misses the point and recuperates the critical phenomenological debate for its own purposes while disregarding the thorny issue of the loss of the natural world. Metz's Zur Theologie der Welt is not, therefore, dealing with the world as a theological problem, but presenting an apology for theology that is neither against nor outside the world. Metz argues, in fact, that theology and a theological understanding of the world are correlates of a worldly self-understanding of the world. Such a theological perspective seems to me insufficient. Why is this?

Because we have no other experience of God (including experience of God's revelation) but the human experience. ${ }^{33}$ The impassable immanence expressed in the phenomenological account of the world is passed over by theological exploration. However, recourse to Weltverständnis in Glaube before engaging sufficiently seriously with Weltlichkeit der Glaube makes Christianity less credible in a context where openness to the divine is no longer a given. This is the main reason theologies of the world recover the conception of the world from a religious perspective but do no justice to the possibility of the religious perception of the world. To address the world as a theological problem we need to look somewhere other than theology.

In the 196os when Patočka was writing his later texts on the natural world and correlational theologies of the world were prevalent, another debate appeared on the intellectual map: 'New Phenomenology', that is, phenomenology (wide) open to 'the religious' and 'the inapparent', later pejoratively labelled 'the theological turn in phenomenology'. However one chooses to describe the movement, one thing is clear: what we are engaging with here is a genuine meeting

33 'Today as yesterday, I have no other route to God except by means of the person I am.' Emmanuel Falque, The Metamorphosis of Finitude: An Essay on Birth and Resurrection (New York: Fordham University Press, 2012), p. 6. 
between phenomenology and theology; we are entering a field where theology and phenomenology not only share a dialogue but mutually interact and transform one another. I find this trajectory of thinking not only inspiring but elucidating for the question of the world as a theological problem.

Phenomenology deals with appearances in the world, but Christian theology is based on the presupposition that the worldliness of this appearing can be interrupted. ${ }^{34}$ Christianity represents the disruption of worldly phenomenality: the New Testament suggests that something/someone not of this world comes into the world. Arguably, theologically attuned phenomenology uncovers several instances of appearances - the gift (Marion), the Life (Henry), the Other (Levinas) - that represent a break with worldly phenomenality. Nonetheless the problem remains: even the unapparent, the inconspicuous, ${ }^{35}$ manifests itself in the way of the world. Otherwise, it would remain utterly inaccessible.

Thus we arrive at the world as a theological problem. The centre of gravity here is the tension between being in the world but not of this world. In theological terms, this is the tension of the possibility of God's appearance in the world but at the same time his coming from the beyond the world, and thus disrupting the world. Paradoxically, as has already been shown above, the response of theology is inadequate. In contrast to the theologies of the world which search for a theologically plausible concept of the world (an a-posteriori defined concept congruent with a-priori received revelation interpreted in a given time and space), phenomenological approaches offer an alternative. For phenomenology, the problem concerns openness to the divine, to religious experience, to the meaning of the world, being-in-the-world-with-others-andwith-God. In other words, the questions Patočka asks in his essay 'Christianity and the Natural World' are radicalized from Levinas to Marion, and more recently with Falque and Lacoste. Felix Ó Murchadha's A Phenomenology of Christian Life even presents the dilemma of the possibility of 'the transcendence of the world in the world', and the challenge of the possibility of 'being-inthe-world which breaks with the world' as the hermeneutical key to the entire movement of the theological turn in phenomenology. ${ }^{36}$ I will now move on to present two apparently contradictory ways of dealing with the world as a theological problem in Michel Henry and Emmanuel Falque. As one of these

34 Lieven Boeve, God Interrupts History: Theology in a Time of Upheaval (New York and London: Continuum, 2007).

35 Jason W. Alvis, The Inconspicuous God: Heidegger, French Phenomenology and the Theological Turn (Bloomington: Indiana University Press, 2018).

36 Felix Ó Murchadha, A Phenomenology of Christian Life: Glory and Night (Bloomington: Indiana University Press, 2013), pp. 1-2. 
approaches may seem negative with respect to the world and the other wholly positive, a caveat is necessary: the point is not to favour one approach over the other (although this may in fact be the case with this author), but to treat the world as a proper theological problem, the problem as expressed in phenomenological explorations, albeit in different ways.

\subsection{Without the World (Michel Henry)}

Michel Henry is rightly described as being among the more hyperbolic, prolific and theologically attuned phenomenologists in France. ${ }^{37}$ It has become de rigueur to present his thought in oppositional terms as a clash between the phenomenality of the world and the phenomenality of Life. Karl Hefty explains the originality of Henry's philosophy as follows: 'Revelation or phenomenality in Michel Henry's sense of the term arrives before and without reference to the world or its temporal horizon. ${ }^{38}$ The question is clear: Why should one include Henry's thought in an exploration of the world if in Henry the world is in fact missing? Or, is there an alternative reading?

In I Am the Truth, the most complex presentation of Henry's (Christian) phenomenology of Life, the author critically distances himself from the Christian tendency to divide reality into 'the here below' and 'the beyond'. ${ }^{39}$ For Henry, there is no 'this world' and 'the other world': there is just one immanent reality. ${ }^{40}$ The Christian failure to conceptualize the world as a horizon, Henry argues, is a logical consequence of the kernel of Christianity, namely, the attention to Life. ${ }^{41}$ In this sense, Henry is really separating the world from Life. He draws his inspiration for this separation from Scripture: 'He who loves his life will lose it; he who hates his life in this world will keep it for eternal life' (Jn 12:25).

In its original sense, Henry explains, 'the world is not a set of things, of beings, the horizon of light where things show themselves in their quality as

37 For a negative account of Henry's phenomenology, see the chapter 'The Surprises of Immanence' in Janicaud, 'The Theological Turn', pp. 70-86. For a neutral description, but one that emphasizes the hyperbolic nature of Henry's language and thought, see Christina Gschwandtner, Postmodern Apologetics? Arguments for God in Contemporary Philosophy (New York: Fordham University Press, 2013), pp. 125-142.

38 Karl Hefty, 'Phenomenality or Revelation: Michel Henry's Approach to Christianity', Analecta Hermeneutica 8 (2016), 197.

39 Michel Henry, I Am the Truth: Toward a Philosophy of Christianity (Stanford: Stanford University Press, 2003), pp. 236-237.

40 Henry's proposal of a radical phenomenology of immanence dates back to his early The Essence of Manifestation (Hague: Nijhoff, 1973).

41 Henry, I Am the Truth, p. 234. 
phenomena. ${ }^{42}$ In agreement with the Husserlian line of thought, the world is the condition of the possibility of representation as well as access to appearances via intentional acts of consciousness. Nevertheless, what Husserl seeks to achieve through the process of phenomenological reduction vis-á-vis the modern scientific mentality that remodelled the entire process of understanding of the world, Henry extends still further. The life-world, even life itself, has been lost as a result of the overwhelming presence of technology, science and the objectivization of everything that is.

Henry turns to Christianity as the container of that truth which escapes the clutches of the truth of the world. This truth says that Life (the invisible, nonintentional) precedes the world (the visible and intentional). In contrast to the external descriptive truth of the world inaugurated by science, Christianity knows a pure phenomenological truth, that is, phenomenality itself without distance. ${ }^{43}$ This truth is experienced directly in life; is Life itself.

It is now clear that Henry's criticism of the world is directed at the 'Galilean' reduction of reality and that he is radicalizing the phenomenological critique of modernity. It is in this sense only that it is possible to say that the phenomenology of Life, together with a particular vision of Christian philosophy in Henry, is 'without the world'. ${ }^{44}$ But in no way is Henry suggesting that Christianity exists in a void. As Henry himself explains: '[Christianity is far] from turning us away from the world. Rather, it is the way to accessing what is real in that world, to accessing unique reality.45 In other words, Henry is providing us with a clear understanding of the world as a genuine theological problem.

The world is neither obliterated nor recuperated. Henry presents the world and life as two ways of approaching and processing the one and only (immanent) reality. There is a hint of immediate, Augustinian (religious) experience in Henry; an implicit Barthian echo claims that 'the relationship of man to God does not pass through the world: ${ }^{46}$ Whatever the case, the world and life are seen here as approaches to reality and to God. We have lost the way of life,

42 Ibid., p. 14.

43 Ibid., p. 25 .

44 Kevin Hart claims: 'Not only is the world of science separated from life but also life is said to be without a world, a horizon of horizons.' Kevin Hart, 'Without World: Eschatology in Michel Henry', in N. Deroo and J.P. Manoussakis, eds, Phenomenology and Eschatology: Not Yet in the Now (Farnham: Ashgate, 2009), pp. 167-192 at p. 171.

45 Henry, I Am the Truth, p. 242.

46 Michel Henry, Phénoménologie de la vie, Tome IV: Sur l'éthique et la religion (Paris: PUF, 2004), p. 131. Murchadha also recognizes a certain Barthian or even more general dialectical-theological tendencies in Henry (but also with regard to other thinkers, for example, Marion). Murchadha, Phenomenology of Life, p. 21. 
Henry argues, because we are too focused on the world and its modern objectivization. ${ }^{47}$ Interestingly, in Patočka we see the opposite argument: we have lost life because we have lost the world in the objective relations of beings which exclude Being (that is Life). Henry's view also contradicts the conclusions of modern theologies of the world. Instead of affirming the world, Henry stresses the distinction between the truth of the world and Christian openness to Life and truth. Which is to say that Henry's phenomenological engagement with Christianity understands that the concept of the world is a theological problem. The lesson from Henry is that neither overcoming nor recuperating the world is the way forward. Whether or not one agrees with Henry's controversial account, the world is undeniably presented in its problematicity. A new reading of Emmanuel Falque, as we will now see, adds to this problematicity.

\subsection{In the World (Emmanuel Falque)}

Emmanuel Falque formulates a devastating critique of Henry and concludes that the 'without the world approach' devalues the Incarnation and renders this fundamental Christian doctrine meaningless for the Christian existence. ${ }^{48}$ Falque therefore represents the counter position to Henry (and Marion, Levinas, et al.), who implicitly follows dialectical theology's dictum of the radical dichotomy between God and the world.

Falque develops a different kind of theologically attuned phenomenology which differs from that of his predecessors and also his contemporaries. ${ }^{49}$ His point of departure can be summarized as follows: we have no other experience of God but the human experience..$^{50}$ This claim is central to our discussion regarding the world as a theological problem.

The concluding chapter (pp. 259-275) of Henry's I Am the Truth is dedicated solely to this issue.

48 '[I]ncarnation probably does not change anything, or changes almost nothing, in Michel Henry.' Emmanuel Falque, 'Is There a Flesh without Body? A Debate with Michel Henry', Journal of French and Francophone Philosophy 24:1 (2016), 139-166 at 163.

49 In an interview with Tarek Dikka and Chris Hacket, Falque situates himself among the third generation of French phenomenologists with an interest in religion. After the first generation of Husserlians (Levinas, Henry) and the second generation of Heideggerians (Marion, Chrétien), Falque claims to follow the path of Merleau-Ponty. This identification also distinguishes him from Jean-Yves Lacoste, the other phenomenologist with a proper university theological training, who leans towards Heideggerian inspirations. Emmanuel Falque, 'The Collision of Phenomenology and Theology', in T.R. Dikka and C. Hackett, eds, Quiet Powers of the Possible: Interviews in Contemporary French Phenomenology (New York: Fordham University Press, 2016), pp. 211-227 at pp. 211-212. 
Falque introduces three concepts: (1) impassable immanence; (2) always believing; and (3) transformation. Accepting Falque's invitation to combine the practices of theology and philosophy, I will point out the phenomenological and theological significance of these concepts.

(1) Falque opens his Metamorphosis of Finitude (part of the Triduum philosophique) with an argument concerning impassable immanence, the crux of which is the question of openness to God. In short, for Falque, there is no desire for God before the experience of finitude - the confrontation with being-in-the-world. Phenomenologically speaking, Falque is following a classical post-Husserlian doctrine that whatever appears, appears to the subject on the horizon of the world. However, he combines this with Heidegger's perspective that the fundamental experience of being-in-theworld is the experience of being-towards-death. Theologically speaking, the appearance of transcendence in the world cannot be conceptualized as the subject's vertical directedness towards an object (above/beyond). Rather, the experience of transcendence is the subject's openness to the appearance in its horizontality (the opening in the world). Finitude is then the first but by no means the last word of the Christian experience. The consequence, however, is that the experience of the world precedes the religious experience. Openness to God comes only afterwards and is mediated by Christ, who came into the world as a human being.

(2) Always believing is the main concern of chapter three of Crossing the Rubicon and can be summarized as philosophical belief, or trust, in the world. It is not so much a concept as the unconditioned a priori of being-in-the-world. Phenomenologically speaking, before reflecting on the world (and our being in the world), we already have the world (and we are in the world). The world is the horizon of our experience: everything that appears to us, appears in the world. Theologically speaking, trust precedes the decision to have faith in God (or take on any other religious belief). Falque explains: 'We adhere to the world in philosophy as we adhere to God in theology in an originary posture - always given in advance - such that philosophical faith in the world heuristically precedes theological faith in God. ${ }^{51}$ In other words, theology cannot ignore its proper place - lieu - that is, humanity and the world.

(3) Transformation is the golden thread of Falque's work and it appears in several instances, such as the transformation of phenomenology by its engagement with the theological (Quiet Powers of the Possible), the trans-

$5^{1} \quad$ Ibid., p. 84 . 
formation of philosophical concepts in the history of theology, ${ }^{52}$ and phenomenological-theological explorations of Eucharistic transformation. ${ }^{53}$ In the context of our question, however, the sense Falque gives to the transformation of the world in the final part of Metamorphosis of Finitude seems to be crucial. Here, Falque 'crosses the Rubicon' between the theological and the philosophical and succeeds in pinning down the meaning of the world as a theological problem. Before going into detail, I will elucidate the meaning of the world according to Falque. Three points must be mentioned.

(A) That which was objectively given in the theological context of the Middle Ages (Christendom) is no longer accessible in modernity. This is true both for philosophy and for science. Philosophy shifts from nature to the human condition and human existence in the world. The point of interest is not the finality of human being (according to its nature), but freedom qua responsibility (taking care of the self) in the world. For science, it has become obvious that, 'to speak of the object in itself in nature - independently of the subject who observes it and who in an act of observation modifies what is observed - does not make, or no longer makes, sense ...${ }^{54}$ In sum, Falque says that the world is more than nature (the object).

(B) The world (in both phenomenology and the Gospels) is a neutral horizon to which everyone is related..$^{55} \mathrm{I}$ - the person - find myself in the world and the world precedes me. The world is always familiar to me and is not therefore a thing (negative or positive). Rather, it is a mode of being (in both phenomenology and Christianity). To put the theological and the phenomenological together, the world as the creation (theology) and die Welt/Lebenswelt (phenomenology) is a horizon of our experience and a relationship to other beings and things.

(C) From the theological perspective, the event of the Resurrection transforms the world and makes the world 'other'. Yet it must be noted that this is not the same as the supposition of another world

Emmanuel Falque, God, the Flesh, and the Other: From Irenaeus to Duns Scotus (Evanston: Northwestern University Press, 2012). 
(beyond/above). Transformation happened in this world, or to paraphrase, in the world which becomes other.

To return to the world as a theological problem in Falque, we can close with the following: theology must start from below, that is, from the world and the human being in the world. This default position requires trust in the world and openness to the appearances of the other(s) in the world. In other words, Falque understands the challenge raised by Patočka (without having any significant knowledge of this author) that the problem of the world in theology translates itself as the problem of openness to God from within the world. There is no path other but being and time, no detour, no way to by-pass the human per se. ${ }^{56}$ Falque therefore suggests a completely different path from, for example, Henry, and chooses to start with human experience, which is the only experience of God one can have. In contrast to theologies of the world which construct their positive approach to the world on the basis of the doctrine of the Incarnation, Falque argues that it is the event of the Resurrection which proves central to the problem. In other words, acceptance of the profane world is the first but not sufficient word about the world. Theology must talk about the transformation of the world.

To summarize, theologically attuned phenomenology understands the tension between the possibility of openness to the divine in the world and the revelation of the divine/the appearance of God who is not of the world. We have seen this tension take on various avatars. Whether it be the world as the unconditioned condition of any experience (Falque), or the critical distance which sees the world as the obstacle of any real experience (Henry), the starting point is always immanence. This is what I include under the rubric 'the world as a theological problem. Phenomenology seems to understand the importance of this issue and provides us with a description of the field. Theology must now offer a response or concede that the only solution available will come from phenomenology - the most productive ancilla theologiae of our time.

\section{4}

\section{Conclusion}

I opened this reflection on the concept of the world in theology with a reference to the Czech phenomenologist Jan Patočka. To allay the understandable fears of some scholars of Patočka's thought, I have no intention of 'baptizing'

$56 \quad$ Ibid., pp. 122-124. 
Patočka and recuperating his thought as a crypto-theology. Like the thinkers of the New Phenomenology, or as I propose calling them 'theologically attuned phenomenologists', I read Patočka's search for the natural world as a reflection on the possibility of the appearance of something which is not of the world in the world; in my view, Patočka opens the way to thinking the world as not only a philosophical problem, but also by challenging theology to think the world as its own problem. This challenge is yet to be taken up by modern theology.

The inquiry into Johann B. Metz revealed interesting differences between the theological and phenomenological approaches. Understandably, Metz (theology) presents the argument from the perspective of faith (Weltverständnis in Glaube), whereas Patočka (phenomenology) explores the human anthropological - understanding of the world which has lost its vertical dimension. Metz draws a positive evaluation of the world from modernity and seeks to show the Christian foundation of the worldliness of the world proclaimed in the modern mentality. He also argues that after the modern anthropological turn, the experience of being in the world is a subject-subject experience. On the other hand, for Patočka (and even more so for Husserl and Heidegger), the modern Weltanschauung promotes objectivity and the objective experience of the world as nature (as constructed by modern science) and in the process loses the subject in the tangle of objective relations. The Being of the subject is downgraded to a being among other things, which leads eventually and inevitably to forgetting about Being itself. And to forget Being is to forget about the world.

How is it possible that theology and phenomenology draw almost opposite conclusions concerning the world on the background of modernity? The answer is clear: theology and phenomenology are referring to different movements of modernity (Neuzeit). Theology sticks to the anthropological turn in the post-Renaissance age, draws a positive evaluation of the world and of human life in the world, and provides it with Christian foundations. It should be noted, however, that theology turns to 'positive sources' of modernity only when the modern Weltanschauung puts Christianity under pressure. In other words, theology recuperates a certain tradition of modernity in the context when modernity, in its most radicalized form, is much more antagonistic to Christianity. By contrast, phenomenology focuses precisely on this radical version of modernity, that is, the appearance of the modern technoscientific rationalism and all its consequences, including the objectivization of the world. In this context, Michel Henry develops a devastating critique of the modern world, ${ }^{57}$ which he applies in his reflection on Christianity as the 
means of resisting the reduction of Life. In a different way, Emmanuel Falque reconsiders the perception of the world interpreted as the human per se. Each of these mutually opposed phenomenological engagements offers a concept of the world in relation to theology and supplies the missing theological elaboration on the problem.

My view is that theology merely recuperates the world and explains how the concept fits the overall narrative of the Christian faith. Even more radically, theology attempts to prove that the way modernity experiences the world is in fact a product of two thousand years of Christian understanding. These correlational tendencies miss the point, however. Theology does not seem to ask the question raised by, for example, theologically attuned phenomenology, namely, how to think the possibility of openness to God in a world which so completely closes off all possibility of such openness. Theology forgets the question of the world in its crudeness.

Theology saves the world for its own internal discourse but achieves little in doing so as it simply removes from the world the aura of an obstacle for a believing soul accustomed to a certain tension, if not antagonistic opposition, between faith and the world. If I had chosen a different theological tradition, such as Barth, von Balthasar or Ratzinger, the antagonism would only have been reinforced. The debate in phenomenology, then, may at first sight appear to be similar in nature to the debate in theology. Falque stands in the tradition of a more open theology (the Concilium style); Henry represents the more conservative wing (the Communio style). ${ }^{58}$ The key difference, however, is that the rival approaches developed by phenomenologists each explore the very experience of being-in-the-world and are not subject to any ready-made solutions.

I have suggested that phenomenologists who engage with the field of theology understand the problem of the world better than theologians themselves. The debate oscillates between understanding the world as the condition of the possibility for any openness to God and the world as a contingent horizon or even the adversary of such openness. These opposing poles also reveal the different position of the subject in the whole process: from an active subject and its search for openness to a passive subject receiving revelation that is not of this world, is revealed in this world, and is despite this world. ${ }^{59}$

$5^{8}$ An elaboration on the interpretation of the theological turn in these terms would require a full-length study. However, it seems reasonable to suggest that the new phenomenology unfolds and even replaces the debate opened in post-Vatican II theology, which nonetheless all too quickly focused on ecclesiological issues at the expense of the academic community and the world in general.

As Kristóf Oltvai pointed out in his response to my paper during its first presentation at 
I do not pretend to be offering the final word on the world as a theological problem in this brief study. I am simply seeking to raise this often-forgotten question and to provoke theology into dealing with the question of the world in its proper setting, which means going beyond the debate of the 196os and drawing inspiration from recent phenomenological discussions. In such a way, the world may once again - or perhaps for the first time - be perceived as a proper theological problem.

\section{Acknowledgements}

This essay was written with the generous financial support of the Austrian Science Fund (FWF) for the project "Revenge of the Sacred: Phenomenology and the Ends of Christianity in Europe" [P 31919].

\section{Bibliography}

Alvis, Jason W. The Inconspicuous God: Heidegger, French Phenomenology and the Theological Turn (Bloomington: Indiana University Press, 2018).

Barbaras, Renaud. L'ouverture du monde: Lecture de Jan Patočka (Chatou: Édition de la transparence, 2011).

Blecha, Ivan. "Pojem světa u Finka a Patočky." In Patočka a filozofia 20. storočia, eds. V. Leško and R. Stojka (Košice: Filozofická fakulta UPJš v Košiciach, 2015), 151168.

Boeve, Lieven. God Interrupts History: Theology in a Time of Upheaval (New York and London: Continuum, 2007).

Falque, Emmanuel. Crossing the Rubicon: The Borderlands of Philosophy and Theology (New York: Fordham University Press, 2016).

Falque, Emmanuel. The Wedding Feast of the Lamb: Eros, the Body and the Eucharist (New York: Fordham University Press, 2016).

Falque, Emmanuel. "Is There a Flesh without Body? A Debate with Michel Henry." Journal of French and Francophone Philosophy 24 (1) (2016), 139-166.

Falque, Emmanuel. "The Collision of Phenomenology and Theology." In Quiet Powers of

the INPR conference in Paris (June 2019), this tension could be translated as a traditional argument between mediatist and immediatist positions concerning religious experience. I am indebted to Oltvai in many other respects, especially his insightful comments on Michel Henry's phenomenology of life, which helped me redefine the final version of the paper. 
the Possible: Interviews in Contemporary French Phenomenology, eds. T.R. Dikka and W.C. Hackett (New York: Fordham University Press, 2016), 211-227.

Falque, Emmanuel. The Metamorphosis of Finitude: An Essay on Birth and Resurrection. (New York: Fordham University Press, 2012).

Falque, Emmanuel. God, the Flesh, and the Other: From Irenaeus to Duns Scotus (Evanston: Northwestern University Press, 2012).

Fink, Eugen. Einleitung in die Philosophie (Würzburg: Königshausen \& Neumann, 1985). Gschwandtner, Christina. Postmodern Apologetics? Arguments for God in Contemporary Philosophy (New York: Fordham University Press, 2013).

Guardini, Romano. Das Ende der Neuzeit: Ein Versuch zur Orientierung (Würzburg: Werkbund Verlag, 1959).

Guardini, Romano. Welt und Person: Versuche zur christlichen Lehre vom Menschen (Würzburg: Werkbund Verlag, 1955).

Hart, Kevin. "Without World: Eschatology in Michel Henry." In Phenomenology and Eschatology: Not Yet in the Now, eds. N. Deroo and J.P. Manoussakis (Farnham: Ashgate, 2009), 167-192.

Hefty, Karl. "Phenomenality or Revelation: Michel Henry's Approach to Christianity." Analecta Hermeneutica 8 (2016), 196-217.

Heidegger, Martin. “The Question Concerning Technology in Heidegger.” In Basic Writings, ed. D.F. Krell (San Francisco: HarperCollins, 1993), 307-342.

Henry, Michel. Barbarism (London: Continuum, 2012).

Henry, Michel. Phénoménologie de la vie, Tome Iv: Sur l'éthique et la religion (Paris: PUF, 2004).

Henry, Michel. I Am the Truth: Toward a Philosophy of Christianity (Stanford: Stanford University Press, 2003).

Henry, Michel. The Essence of Manifestation (Hague: Nijhoff, 1973).

Husserl, Edmund. The Crisis of European Sciences and Transcendental Phenomenology: An Introduction to Phenomenological Philosophy (Evanston: Northwestern University Press, 1970).

Janicaud, Dominique. “The Theological Turn of French Phenomenology.” In Phenomenology and the 'Theological Turn': The French Debate, D. Janicaud et al. (New York: Fordham University Press, 2000), 16-103.

Kohák, Erazim. "The Crisis of Rationality and the Natural World." The Review of Metaphysics 40 (1) (1986), 79-106.

Metz, Johann B. Zur Theologie der Welt (Main-München: Matthias-Grünewald, Kaiser Verlag, 1969).

Murchadha, Felix Ó. Phenomenology of Christian Life: Glory and Night (Bloomington: Indiana University Press, 2013).

Novotný, Karel. "Pohyb života a svět: O fenomenologii a metafyzice světa u Jana Patočky." Reflexe 53 (2017), 139-155. 
Patočka, Jan. The Natural World as a Philosophical Problem (Evanston: Northwestern University Press, 2016).

Patočka, Jan. "The Natural World Remeditated Thirty-Three Years Later." In The Natural World as a Philosophical Problem (Evanston: Northwestern University Press, 2016), 115-18o.

Patočka, Jan. Body, Community, Language, World (Chicago and La Salle: Open Court, 1998).

Patočka, Jan. An Introduction to Husserl's Phenomenology (Chicago and La Salle: Open Court, 1996).

Patočka, Jan. Heretical Essays in the Philosophy of History (Chicago and La Salle: Open Court, 1996).

Patočka, Jan. "Theologie a filosofie." In Sebranné spisy Jana Patočky, vol. ı. Péče o duši, I, eds. I. Chvatík and P. Kouba (Praha: Oikoymenh, 1996), 15-21.

Patočka, Jan. "Le christianisme et le monde naturel." Istina 38 (1) (1993), 16-22.

Patočka, Jan. "La surcivilisation et son conflit interne." In Liberté et sacrifice (Grenoble: J. Millon, 1990), 99-177.

Patočka, Jan. "The Natural World and Phenomenology." In Jan Patočka: Philosophy and Selected Writings, ed. E. Kohák (Chicago: University of Chicago Press, 1989), 239-272.

Patočka, Jan. "Spiritual Crisis of European Humanity in Husserl and Masaryk." In On Masaryk, ed. J. Novák (Amsterdam: Rodopi, 1988), 97-109.

Petříček, Miroslav. "Jan Patočka a myšlenka přirozeného světa." Filosofický časopis 38 (1-2) (1990), 22-43.

Ricoeur, Paul. "Jan Patočka: de la philosophie du monde naturel à la philosophie de l' histoire." Studia Phenomenologica 7 (1) (2007), 193-200.

Schillebeeckx, Edward. World and Church (London and New York: T\&T Clark, 2014).

Simmons Aaron J. and Bruce E. Benson. The New Phenomenology: A Philosophical Introduction (New York: Bloomsbury, 2013).

Vattimo, Gianni. After Christianity (New York: Columbia University Press, 2002). 